\title{
Retraction ends furore over cancer vaccine
}

Alison Abbott, Munich

The authors of a paper, published three-anda-half years ago in Nature Medicine, that claimed that patients with terminal kidney cancer had been successfully treated with individualized cancer vaccines, have finally retracted their work.

Scientists in Germany, where the clinical studies were carried out, say they are relieved that the long-drawn-out affair is closed. But they claim that the delay in correcting the record has sapped researchers' morale.

An investigation committee at the University of Göttingen reported last November that the paper "failed to meet the requirements of good scientific practice". It found the lead author, Alexander Kugler, guilty of gross negligence, but cleared the other 14 co-authors of scientific misconduct (see Nature 420, 258; 2002).

The contested vaccine trials, sponsored by the Bad Homburg-based healthcare company Fresenius, were suspended more than a year earlier following allegations of irregularities in clinical practice, and the university had been accused of being slow to complete its investigation (see Nature 417, 6;2002).

The retraction appears in this month's issue of Nature Medicine, with an editorial explaining why it took the journal a further ten months from the committee's ruling to persuade the reluctant authors to retract and to agree a form of words (Nature Med. 9, $1221 ; 2003)$. "We wanted the authors themselves to retract rather than issuing a retraction from the journal," says editor Beatrice Renault. "It is more meaningful if authors take the responsibility, and it has more power within the scientific community."

One of the authors, Rolf-Hermann Ringert of the University of Göttingen, says that despite errors in the publication -

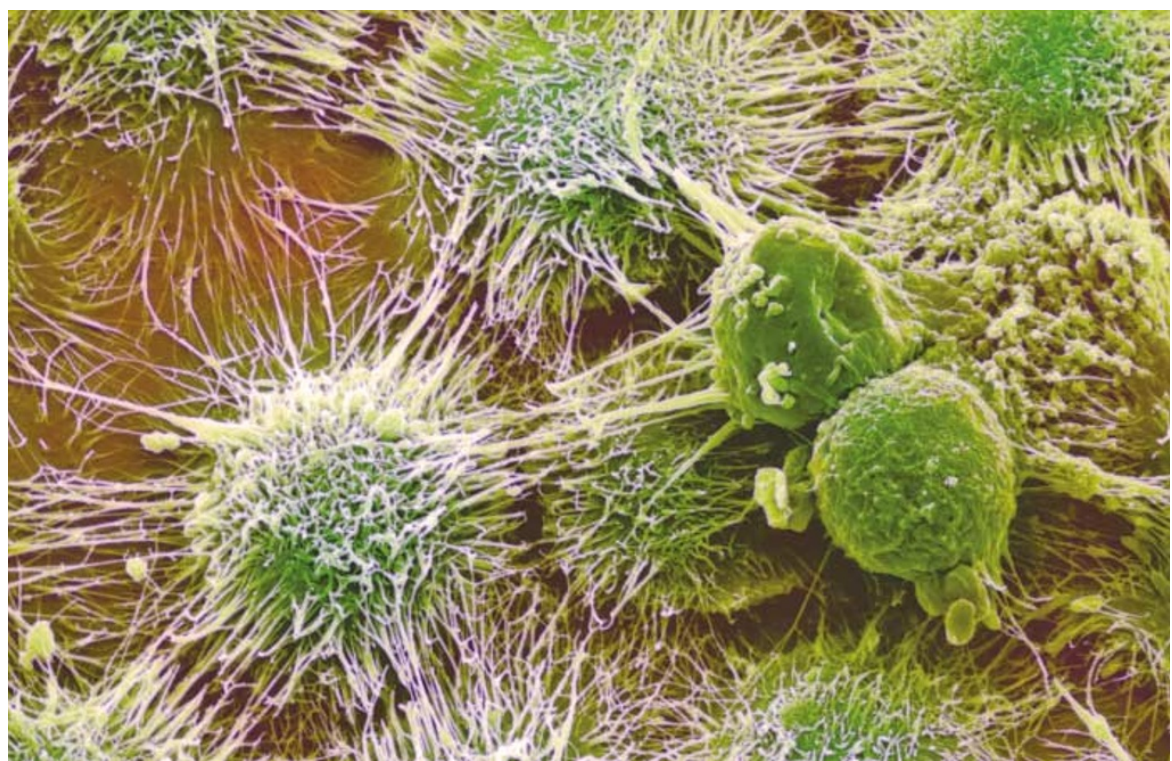

Cancer cells (green) in kidneys: at the centre of a misconduct case involving vaccine trials.

which include inaccuracies in the primary data and inclusion of patients who did not fulfil the requirements of the trial — he tried for a long time to persuade the journal to publish a list of detailed corrections, rather than a retraction. He says that he still stands by the authors' central claim to have proven the principle that this type of 'fusion' cancer vaccine is effective.

Vaccines of this sort fuse patients' tumour cells with healthy dendritic cells, which present antigens to the immune system in a way that signals that the antigens are foreign and should be destroyed. When the patients are injected with the fused cells, their immune system should be alerted to destroy the cancer cells that they had previously tolerated.

Others working on fusion vaccines say that the Kugler case has had a negative effect on funding in this area and has made it harder to publish results. But groups in the United States and Japan have now reported anticancer activity of modified fusion vaccines in early-phase trials in breast cancer and in glioma, a type of brain tumour. Fresenius is planning a further trial on kidney cancers at the University of Göttingen, applying optimized fusion technologies, a spokesman for the company says.

Ulf Rapp, a cell biologist at the University of Würzburg and head of a task force that investigated an earlier, unrelated scientific misconduct case, says that the retraction "is the right outcome, but it could have come faster. Journals owe it to their image to take matters into their own hands when an investigation exposes errors and authors are hard to track down, or reluctant to retract."

\section{Columbia inquiry prompts White House strategy review}

\section{Tony Reichhardt, Washington}

The White House will conduct a review of US space strategy in the wake of last week's hard-hitting report on the loss of the space shuttle Columbia - and members of Congress have joined NASA in pledging to reform the space agency itself.

But early soundings in Washington suggest that the manned-spaceflight programme will face an uphill struggle to attract the extra resources that, the report implied, it needs to operate more safely.

The Columbia investigation, led by retired Navy admiral Harold Gehman, was unsparing in its criticism of NASA, as expected (see Nature 424, 863; 2003).
The report also castigated the White House and Congress for underfunding the shuttle programme, which had its budget cut by $40 \%$ in real terms during the $1990 \mathrm{~s}$.

In a press conference held on 26 August to unveil the report, Gehman called for "a very vigorous public-policy debate about what do we do now" in space, and warned that human spaceflight, if done safely and well, will require much more resources than the United States has been spending. “This stuff is not cheap," he said.

But in the immediate aftermath of the report, few congressional leaders were ready to pledge more money to the space programme. Sherwood Boehlert
(Republican, New York), who chairs the House of Representatives science committee, says that if NASA "is expecting us to write a blank cheque, we're unwilling to do so". Nor is it certain, he adds, that the astronaut programme will continue. "My own predisposition is to continue manned spaceflight, but not at any cost, and not at any risk." Any push to increase NASA funding will have to come from the Bush administration. "We're going to have to have clear direction from the White House," says Boehlert.

Last year the White House Office of Science and Technology Policy and the National Security Council led a review of US 


\section{Peers rally in support of accused scientist}

\section{Erika Check, Washington}

Two leading US scientific organizations have lambasted the government's treatment of an infectious-disease expert who faces multiple criminal charges after mishandling plague samples.

In a letter to Attorney General John Ashcroft, Bruce Alberts, the president of the National Academy of Sciences, and Harvey Fineberg, who heads the Institute of Medicine, said that the prosecution of the researcher, Thomas Butler of Texas Tech University in Lubbock, was endangering US bioterrorism research.

Butler was arrested in January for giving incorrect information about samples of the plague bacterium Yersinia pestis he had transported to Texas from Tanzania. Initially, Butler, who was chief of infectious diseases at Texas Tech, had reported that the samples were lost, and then confessed that he had destroyed them. The US Department of Justice charged Butler with illegally transporting the vials, lying to federal agents, and filing a false 2001 tax return.

If convicted on all current counts, Butler could pay as much as $\$ 3.6$ million in fines and go to prison for 74 years, according to the National Academies' Committee on Human Rights. Additional charges are expected to be filed before his trial, set for 6 October in Lubbock.

In their letter to Ashcroft, Alberts and Fineberg wrote: "We are particularly concerned about the impact that Dr Butler's case may have on other scientists who may be discouraged from embarking upon or continuing crucial bioterrorism-related scientific research - thereby adversely affecting the nation's ability to fully utilize such research capabilities in preparing

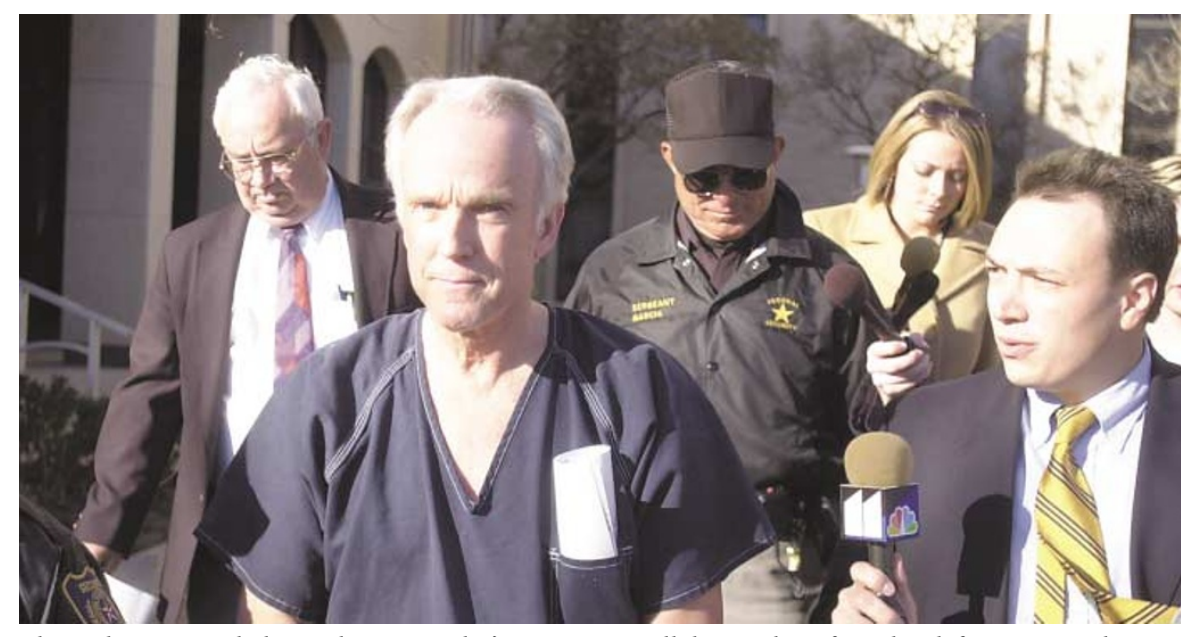

Plagued: scientists believe Thomas Butler's treatment will deter others from biodefence research.

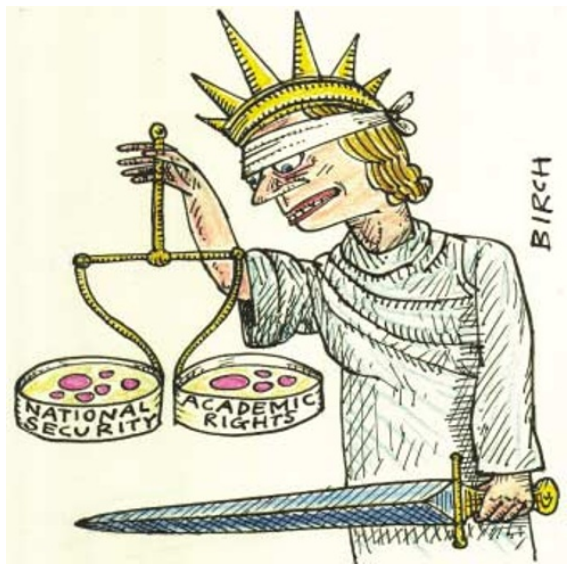

defenses against possible bioterrorist attacks."

On 28 August, the human-rights committee wrote to its membership - 1,700 senior scientists, engineers and doctors 21 asking them to support Butler by writing to Texas Tech, the US government and Butler. It also requested donations for Butler's defence space policy that was nearly complete at the time of the Columbia accident. That project was shelved but now is being revived with the Gehman report in mind, for completion early next year, just in time to feed into the Bush administration's 2005 budget request.

Meanwhile, NASA may report as early as this week on its latest plan for returning the shuttle to flight. The earlier target launch date of next spring now looks unlikely, as does the pre-accident plan to complete the US segments of the International Space Station within a year of the next shuttle launch. The Gehman panel's report cited pressure to finish the station on schedule as a contributing cause of the accident.
The current US federal deficit and the mounting costs of the war in Iraq make any grand expansion of NASA's budget unlikely, but some commentators say that political factors may be coming together for a renewed US commitment to human space exploration. Howard McCurdy, a spacepolicy expert at the American University in Washington, says that President Bush may be under pressure to make such a commitment. "Historically," he says, "no major political figure with the authority to make the decision has ever wanted to put his or her fingerprints on a decision to start closing down the manned-spaceflight programme."
— so far, he has paid his lawyers $\$ 400,000$, the alert says.

Nobel laureate Torsten Wiesel, who chairs the human-rights committee, says that the only other case in which the committee has taken similar steps on behalf of a US scientist was the prosecution of Wen Ho Lee, the Los Alamos National Laboratory researcher who was accused of stealing US nuclear secrets in 1999.

But the committee was compelled to act in Butler's case because of what seemed to be a severity of punishment out of proportion to his crime, Wiesel says. "Rather drastic steps have been taken against him, and we want to ensure that he is being dealt with properly by the justice department and the university," he explains.

Texas Tech has prevented Butler from returning to its campus at Lubbock and is planning to testify against him at his trial; Butler, meanwhile, is becoming depressed, Wiesel says.

Wiesel also warns of the case's broader significance. He says that several scientists have told the National Academies that the Butler prosecution is scaring US researchers away from biodefence work, because they perceive Butler to be a scientist who has merely been caught unaware by the rules.

"It's a serious mistake because he is one of the internationally recognized experts in plague," Wiesel says. "This has certainly sensitized the community, which is not helpful if you really are concerned about bioterrorism."

Steven Block, a biophysicist at Stanford University, adds: "The Department of Justice should go after individuals who pose serious, credible threats to our national security, not hapless biomedical scientists who are simply pursuing their research, but failing to fill out the mounds of paperwork mandated by the bureaucracy." 


\section{Ocean drilling project gets international relaunch}

San Diego An international scientific programme that drills cores in the ocean floor gets a new name at the end of this month, after nearly 20 years studying the Earth and its climate.

The Ocean Drilling Program (ODP), which will be formally wrapped up at the end of September, drilled at 650 sites, taking in every ocean apart from the ice-covered Arctic. Its last trip ended at the beginning of September, when the Resolution returned from drilling a 2-kilometre core near Bermuda. This core will provide data from about 145 million years ago when North America and Europe were joined and the Atlantic Ocean did not yet exist.

On 1 October the ODP will be replaced by another international project, the Integrated Ocean Drilling Program (IODP). More than half of the ODP was funded by the United States, whereas the IODP's larger budget will be mainly split between the United States and Japan, which has

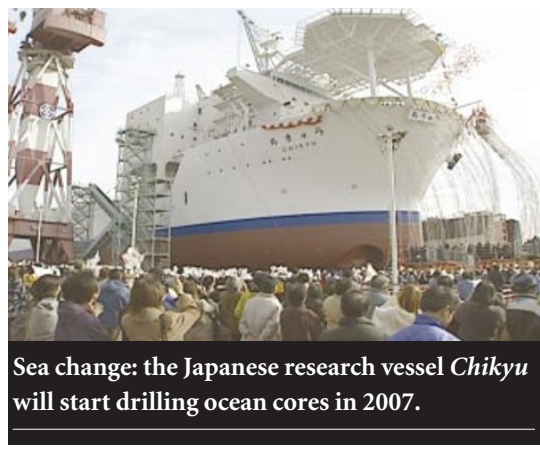

contributed a new research ship, the Chikyu. The IODP's first project is scheduled for next June.

\section{NASA boldly goes into the world of academia}

San Diego The University of California at Santa Cruz has won a \$330-million contract to head a joint research effort with the NASA Ames Research Center.

Under the deal, signed on 15 September, university scientists will conduct mission-

Editorial policy changes Nature is extending its policy on competing financial interests to include the authors of Review and Progress articles. Further extensions are being considered.

Also, Nature has extended its policy on peer review to include considerations of risks such as assisting bioterrorism. See www.nature.com/nature/submit/policies for further details.

specific projects for NASA in such areas as information technology, biotechnology and astrobiology. The centre will be based at NASA Ames' site at Moffett Field near San Francisco.

\section{Europe's global navigation system heads east}

London European plans to build an alternative satellite navigation system to rival the US-run Global Positioning System (GPS) received a boost last week when China agreed to back the project.

European Commission officials say that China is expected initially to invest at least E200 million (US\$230 million). Chinese officials will be trained at a new centre for satellite navigation opened on 19 September at Beijing University.

The Galileo system, which will cost more than $\mathrm{E} 3$ billion and is due to be operational by 2008 , will be made up of 30 satellites. Its backers say the new system will also provide navigational information faster than GPS.

\section{Correction}

Abbott, A. Nature 425, 4; 2003.

In this News article, it was wrongly stated that the cancer-vaccine trial reported in Nature Medicine in 2000 , which has now been retracted, was supported by the healthcare company Fresenius. 